УДК 930(438).073 «Кубаля»:94(477) «17/18»

DOI 10.24919/2519-058x.5.117205

Оксана ПЕСТРИКОВА, orcid.org/0000-0002-7044-9765 аспірантка кафедри історіографії, джерелознавства та архівознавства Дніпровського національного університету імені Олеся Гончара

(Україна, Дніпро) pestrykova.o.v@gmail.com

\title{
ФОРМУВАННЯ ТА ЕВОЛЮЦІЯ ОБРАЗУ БОГДАНА ХМЕЛЬНИЦЬКОГО У ТВОРЧОСТІ ЛЮДВІКА КУБАЛІ
}

У статті вперше узагальнюється і аналізується історіографічна традииія дослідження особливостей образу Б. Хмельницького в інтерпретаиії відомого польського історика Л. Кубалі. Окреслені особливості його стилю історіописання, які вилинули на формування образу українського гетьмана у праиях ученого. Виокремлено два етапи формування та зміни образу Б. Хмельнищького у творчому доробку історика. Зроблено висновок щодо чинників, які могли вплинути на специфічні підходи у відтворенні постаті українського гетьмана Л. Кубалею.

Ключові слова: Л. Кубаля, Б. Хмельниџький, історіографічна традиція, польська історіографія кіния XIX- початку XX ст., Хмельниччина, «Szkice historyczne».

Jim. 33.

Oksana PESTRYKOVA, PhD student of Historiography, Knowledge of Sources and Knowledge of Archives Chair Department, Oles Honchar Dnipro National University (Ukraine, Dnipro) pestrykova.o.v@gmail.com

\section{FORMATION AND EVOLUTION OF THE BOGDAN KHMELNITSKY IMAGE IN THE WORKS OF LUDWIK KUBALA}

In this scientific paper at the first time the historiographical tradition of studying the characteristic of $B$. Khmelnytsky's image in the interpretation of the famous Polish Historian L. Kubala was analysed and summarized. In L. Kubala's studies, B. Khmelnitsky was a significant character. Most of the researchers who drew attention to the image of the Cossack hetman in the historian's works emphasized the complexity and controversy of this character. The views of the Polish historian by B. Khmelnytsky's figures are mainly static, that is, without changing. Most historians touched on this problem in the context of more specific problems or in synthetic reviews of the history of events of the region, of which L. Kubala had written. An interesting attempt to analyse the general image of B. Khmelnitsky in the works of the Polish historian was done by A. Tkachuk. The author noticed the difference in the image of B. Khmelnitsky in the first two volumes of «Historical essays» and in later studies.

As a result of this article was singled out two stages of the formation and change of the image of $B$. Khmelnitsky in the work of L. Kubala. The first works mostly were based on the Polish sources, like chronicles Y. Rudavsky, $V$. Kohhovsky, J. Yerlich, which did not describe the person and activities of the Cossack Hetman in a positive way. Therefore, L. Kubala, following to the source, depicted B. Khmelnitsky mostly as an enemy. Also, the influence on his scientific works L. Kubal's dramatic heritage cannot be ignored. With a high degree of probability, it is possible to assume that the drama characteristics of B. Khmelnytsky were transferred to essays from unpublished drama "Rus»" ("Bogdan Khmelnytsky»). That influence could be confirmed by the presence in the scientific works of author's empathy and the formation of a structure "hero-antihero» in the "Historical Essays».

The second stage of the historian's research was marked by a changing of approach to writing essays and expanding of the source base by Cossack origin sources. In particular, the number of used materials from "AYZR» has considerably increased. Introduction of these materials affected on the historian's perception of Hetman and his activity. As a confirmation of such changing could be an author rejection from the emphasis on of an enemy image to the image of a statesman. Also, L. Kubala tried to present in his works comparisons of views on the activity of $B$. Khmelnytsky from both opposing representatives.

Key words: L. Kubala, B. Khmelnytsky, historiographical tradition, Polish historiography of the end XIXthXXth., Khmelnytsky Uprising, «Historical Essays».

Ref. 33. 
Оксана ПЕСТРИКОВА,

аспирантка кафедры историографии, источниковедения и архивоведения Днепровского национального университета имени Олеся Гончара (Украина, Днипро) pestrykova.o.v@gmail.com

\section{ФОРМИРОВАНИЕ И ЭВОЛЮЦИЯ ОБРАЗА БОГДАНА ХМЕЛЬНИЦКОГО В ТВОРЧЕСТВА ЛЮДВИКА КУБАЛИ}

В статье впервые обобщается и анализируется историографическая традиция исследования образа Б. Хмельницкого в интерпретации известного польского историка Л. Кубали. Представлень особенности его стиля историописании, которые повлияли на формирование образа украинского гетмана в работах ученого. Выделены два этапа формирования и изменения образа Б. Хмельницкого в творческом наследии историка. Сделан вывод о факторах, которые могли повлиять на специифические подходы в отображении личности украинского гетмана Л. Кубалей.

Ключевые слова: Л. Кубаля, Б. Хмельницкий, историографическая традиция, польская историчография кониа ХІХ - начала ХХ в., Хмельниччина, «Szkice historyczne».

Лиm. 33.

Постановка проблеми. Найважливіше і найбільш якісне наукове дослідження Л. Кубалі серія «Історичні нариси» («Szkice historyczne») - було присвячене досить стислому проміжку часу, але водночас надзвичайно насиченому бурхливими та визначними подіями для історії Речі Посполитої, а саме 1648 - 1660 рр., тобто добі козацько-польського протистояння та так званого Потопу. До польської історіографії Л. Кубаля увійшов як дослідник, який мав особливий стиль історіописання. Цю особливість відзначали ще сучасники історика. Яскравість та легкість висвітлення сюжетів польської історії робили його твори одними з найбільш читаних у другій половині XIX - на початку XX ст. Сучасна познанська дослідниця В. Юлковська у статті, присвяченій аналізу праць львівських польських істориків К. Шайнохи та Л. Кубалі, вважає головною рисою, притаманною їхнім працям, своєрідну белетризацію наукового тексту за допомогою вписування у нього уривків з історичних джерел, діалогів, монологів, демонстрації настроїв героїв тощо. На думку авторки, подібний підхід виконував важливу функцію опису минулого для читачів. Власне сам Л. Кубаля неодноразово зазначав у своїх дослідженнях, що він особисто завжди намагався «подати найбільш иікавий образ минулого для намого читача» (тут і далі переклад з пол. мійО. П.) $[12,63-67]$.

Людвік Кубаля орієнтувався переважно на широке, непрофесійне коло читачів, при цьому, напевно, ставив перед собою й якусь прагматичну або утилітарну мету. Зокрема варшавський дослідник 3. Ромек назвав це своєрідною національною педагогікою історика [29, 163]. Л. Кубаля вбачав у історії передовсім приклади для життя польського суспільства, особливо в умовах відсутності держави. Так, у вступі до третього тому «Історичних нарисів» історик підкреслив: «Для нас у сьогоднішньому стані знання історії батьківщини має серйозніше значення не лише тому, що додає значення в очах своїх та іноземців, підносить патріотизм, а й коли переривається традиція і мовчать спогади, історія пробуджує їх до життя. (...) Історія (...) правди вчить і людей спільним минулим і надією поєднує» [24, V].

Дослідники наукових праць Л. Кубалі відзначали вплив на його доробок творчості англійського драматурга В. Шекспіра $[8 ; 11]$. Про його захоплення творчістю цього письменника свідчать авторські переклади його творів польською, зроблені істориком під час ув'язнення у Йозефтадті [33]. В. Юлковська вважає, що саме з драм англійського письменника Л. Кубаля запозичив своєрідний спосіб зображення головних героїв та побудову сюжетної напруги $[11,164]$.

Історичні постаті у творах Л. Кубалі посідають не останнє місце. Слід зазначити, що кар'єру він розпочинав саме як драматург. Драматургічний доробок його не був надзвичайно багатим: Л. Кубаля написав всього дві драми «Gliński» [16], та «Ruś» («Bohdan Chmielnicki») [32]. Як бачимо власне з самих назв, автор присвятив їх реальним історичним постатям. Перше його наукове дослідження теж мало біографічний характер. Це була розвідка присвячена С. Оріховському 
[23]. Дослідження, за яке історик отримав більш широке наукове визнання, стосувалося життя та діяльності коронного канцлера Є. Оссолінського [18; 17].

Окремого нарису, який би стосувався постаті Б. Хмельницького, у творчому доробку Л. Кубалі немає, проте, зважаючи на описуваний істориком період, особистість гетьмана була присутня у більшості його текстів.

Аналіз досліджень. Одним із перших, хто звернув увагу на особливості характеристики образу Б. Хмельницького у творчості Л. Кубалі, був відомий український історик М. Грушевський. Зокрема, він протиставив образ гетьмана у польського історика тій негативній оцінці постаті Б. Хмельницького, яка присутня, скажімо, у дослідженнях П. Куліша, П. Буцинського та Ф. Равіти-Гавронського $[1,1485]$. М. Грушевський назвав Л. Кубалю одним із найбільших панегіристів гетьмана $[4,309]$. Він також зазначив, що «похвальне слово Хмельницького було звернене спеціяльно против польських письменників, які продовжують хибну політику легковаження Хмельницького, його талантів і їх переваги над польськими противниками» [1, 1485, 4, 314].

В «Огляді української історіографії» схвально оцінив образ Б. Хмельницького, поданий в «Московській війні» («Wojna Moskiewska») Л. Кубалі, відомий український історик Д. Дорошенко. Він назвав характеристику козацького гетьмана у польського колеги «зразком об'єктивності», який незважаючи на те, що гетьман був ворогом польського народу, не позбавлений великого організаторського, військового та політичного хисту $[1,152]$.

Переважно образ Б. Хмельницького у трактуванні Л. Кубалі розглядався істориками не спеціально, а у контексті вивчення тих чи тих проблем: загалом військової справи тієї доби, укладення угоди в Переяславі тощо. Так, український діаспорний дослідник Дж. Басараб назвав Л. Кубалю неперевершеним в описі персоналій та воєнних дій. Зокрема, на його думку, ним досить яскраво був зображений і Б. Хмельницький, передовсім як дипломат. Згідно з ним, успіх козаків у зовнішній політиці був обумовлений значною мірою особистою участю гетьмана. Він також підкреслив, що Л. Кубаля не був тенденційним у питанні зображення гетьмана, а намагався проаналізувати його діяльність більш детально [9, 118-121].

Волинський дослідник І. Ярмошик сконцентрував увагу на дослідженні польськими істориками битви під Берестечком. Зокрема, він торкнувся і нарисів Л. Кубалі. На його думку, останній зобразив гетьмана як талановитого полководця, але зовсім безпідставно звинуватив у пияцтві [6, 3-4]. Так само вважає сучасний польський історик Т. Срогош, який присвятив власну розвідку аналізу образів козацьких ватажків на сторінках нарисів Л. Кубалі. На думку дослідника, Л. Кубаля, створивши цілу галерею козацьких портретів, найбільшу увагу звернув на особу Б. Хмельницького. Згідно з ним, козацький гетьман - це одна з найбільш цікавих та водночас провокаційних історичних постатей. 3 одного боку, Л. Кубаля не применшував талантів козацького гетьмана, а 3 іншого - акцентував увагу на його вадах, наприклад на пияцтві [29, 89-91].

Діаспорний дослідник Ф. Сисин звернув увагу на те, що оцінка діяльності українського гетьмана Л. Кубалею була дуже схожою на ту, якої дотримувалися представники державницької школи в українській історіографії перед початком Першої світової війни. Тобто він бачив Б. Хмельницького представником домінуючої сили у Східній Європі, як, скажімо, О. Кромвеля - у Західній. Згідно з ним, здатність гетьмана контролювати ситуацію, майстерність налагодження ним міжнародних відносин, його харизматична персона поставили Польщу на коліна і залякували її навіть 3 могили ще довго після його смерті [31, 537-539].

На відміну від вищезгаданих досліджень, які розглядали це питання у контексті більш широких проблем, розвідка херсонської дослідниці А. Ткачук була присвячена винятково аналізу постаті Б. Хмельницького у творчості польського історика [5]. Важливо, що у цьому дослідженні помітні перші спроби зафіксувати різницю між зображенням постаті Б. Хмельницького на ранньому етапі досліджень та у пізніших працях історика. А. Ткачук звернула увагу на те, що у перших нарисах історик не був прихильником Б. Хмельницького, а вже пізніше намагався представити цю постать більш об’єктивно. На думку авторки, через відсутність критичного підходу до джерел, а також слабкість історіографічної традиції у тогочасній польській історичній науці Л. Кубаля мав схильність дещо демонізувати постать гетьмана [5, 139-140]. Проте загалом це питання в сучасної української дослідниці не знайшло більш широкого висвітлення. 
Мета статті - продемонструвати формування та зміну образу Б. Хмельницького в науковому доробку польського історика Л. Кубалі, а також охарактеризувати основні риси, притаманні йому, та встановити причину появи тих чи тих його характерних елементів.

Виклад основного матеріалу. Умовно творчість Л. Кубалі можна розділити на два періоди. Перший - 3 початку 1880-х рр. до 1910 р., коли було опубліковано перші два томи «Історичних нарисів» та монографія «Сжи Оссолінський», та другий (1910 - 1923), коли вийшло друком продовження «Історичних нарисів». Відповідно можна розділити на два етапи і процес формування образу Б. Хмельницького у дослідженнях історика.

Слід зазначити, що перші два томи «Історичних нарисів» - це не цілісне дослідження, а насамперед збірка описів найбільш яскравих подій перших років правління Яна Казимира (1648 1653), тобто найбільш активної фази козацько-польського протистояння. Враховуючи те, про які саме події писав історик, особа Б. Хмельницького зустрічається в переважній більшості нарисів і ій̆ присвячено чимало його уваги.

Цікаво, що спочатку історик переважно називав Б. Хмельницького «бунтівником» та «неприятелем». Так, у нарисі «Облога Збаража та мир під Зборовом» Л. Кубаля наголосив, що невідомо «з яких причин - (...) - 1648 р. Запорізькі козаки, підбурені одним бунтівником, (...) піднесли рокош проти Речі Посполитої» $[21,103]$. Також історик вбачав у гетьмані головну причину неможливості залагодження конфлікту: «Людина, через яку мільйон людей потрапило до неволі, яка своєю особою становила, можна сказати, єднання Запоріжжя з ордою, повинна бути обезвладнена раз і назавжди. Допоки він щзось значив, мир не був можливий; доки він гетьманував, не можна було робити поступок для козаків» [17, 251].

У першому та другому томах «Історичних нарисів» Л. Кубаля спеціально не торкався питання про причини повстання. Проте він досить часто вказував, на те, що Б. Хмельницьким переважно керувало бажання помсти за особисті кривди з боку Д. Чаплинського $[21,152]$. Більше уваги на цей сюжет історик звернув у монографії «Єжи Оссолінський». Зокрема, він зазначив, що після невдалих спроб знайти справедливість у Варшаві, окрім здобуття співчуття короля Владислава IV та однієї його поради («Чаплинський має зброю, і ти маєш зброю, так обороняйся»), Б. Хмельницький підняв повстання через власну мету, скориставшись несприятливими для польської влади умовами в українських воєводствах [17].

Особливо яскраво образ Б. Хмельницького розкривається Л. Кубалею у нарисах, присвячених битвам та військовим кампаніям. Такими у перших двох томах стали «Облога Збаража і мир під Зборовом» [21], «Битва під Берестечком» [14], «Криваві сватання» [19] та «Жванецька виправа» [26]. Л. Кубаля неодноразово отримував схвальні відгуки за свої особливо барвисті та детальні описи військових кампаній. Проте історики військової справи, досліджуючи творчість Л. Кубалі, вказували на певні недоліки у цих нарисах. Особливо це стосується випадків, коли в польського історика йшлося про кількість військ супротивника. Так, для Л. Кубалі було характерним перебільшення кількості військ супротивника і натомість зменшення чисельності польського війська $[10,33]$. Також недоліки в працях польського історика помітні в описах тактики чи перебігу бойових дій $[27,110-111]$. Можна припустити, що для історика не була важлива точна кількість військ, а його метою радше було вразити читача масштабністю події, подати яскраву картину перебігу переможних для польського війська битв.

Окрім того, нариси, присвячені битвам та облогам, у Л. Кубалі мають суб'єктивний характер, адже історик виразно брав сторону польського війська, називаючи його представниками «нашими» $[21,103,105 ; 14]$. Власне, протиставляючи «своїх» та «чужих», Л. Кубаля у нарисах сформував образ героя та антигероя. Таким героєм став для нього Ярема Вишневецький: «князь цей, улюбленець цілого народу (...) Військо, прославляючи героя, скількома битвами та перемогами уславленого, не хотіло мати іншого лідера» [21, 107]. Відповідно антигероєм та неприятелем був гетьман Б. Хмельницький. Саме цим можна пояснити приписування Л. Кубалею суто негативних якостей гетьману в цих нарисах. Зокрема, однією з таких характеристик $є$ підкреслене пияцтво Б. Хмельницького: «усі військові дї̈ залежали від того, чи був гетьман п'яний, чи тверезий. Від того також залежала карність і порядок в таборі. Коли він пив, пило цүіле військо...» $[14,261]$. 
У нарисі «Битва під Берестечком» Л. Кубаля зобразив гетьмана з досить демонічними рисами: «Коли, оточений владиками, хрестами, світлом, серед співів, дзвонів, кадил і иілої пишноти костельної, в червоному одязі, в князівській шапчі на голові вийшов з намету і понурим оком провів доокола, відразу порядок і дисиипліна поверталися до табору. Тремтіло все, коли на чолі полковників проходив шеренги, коли злився, ричав як буря, кляв на всі сторони світу і пекла і страшив людей своїм жахливим голосом, червоним обличчям, кривавими очима і спіненими устами» [14, 247]. Саме на образ такого українського гетьмана звернув увагу польський письменник Г. Сенкевич, підкресливши, що в цьому описі міститься «иілий образ того страшного чоловіка, який, окрім всього, будить у нас подив і заџікавлення. То постать покрита до изього часу якоюсь таємницею»» [28, 693].

Взагалі Л. Кубаля показав Богдана Хмельницького як досить суворого командувача, який піде на будь-які жертви, щоб досягти поставленої мети: «Хмельнищький бачучи, щуо штурм не вдався, крові козацької не жаліючи, вирімив розпочати облогу (...) виставив усі сили і не щзадив крові $i$ людей, аби закінчити зі Збаражом»» [21, 126].

Для досліджень Л. Кубалі характерна також авторська емпатія, тобто спроба проникнути у внутрішній світ героя [7]. Зокрема, описуючи попередні домовленості польського короля з Б. Хмельницьким під Зборовом, історик намагався увійти у становище гетьмана: «Тяжча була справа 3 Хмельницьким (...) Усі його приготування, надї зазнали невдач. Що для нього було 40000 козаків, коли він мав в рази більше; щзо для нього гетьманство, коли він хотів і мав удільну владу? Його обічянки і погрози пішли в ніщо, хлопська чернь мусила повернутись у підданство, орда з королівського дозволу могла брати в ясир людей, яким він свободу обіияв» [21, 151]. Майже так само було й у таборі під Берестечком: «Гетьман козачький ходив як неприкаяний по наметах, часами ніби прокидався від страшного сну, розкидав накази, грозив иілому світу, кляв $i$ знову впадав в апатію $i$ - пив цілими днями. (...) Що творилося в душі того чоловіка, який на все знаходив рімення, $a$ тільки для себе спокою знайти не міг, того ніхто точно не знав... » $[14,261]$.

Слід підкреслити, що перші два томи нарисів історик побудував переважно на польських хроніках та щоденниках. Зокрема найбільш часто він посилався на «Літописець, або Хронічку різних справ і подій...» Й. Срлича, «Аннали Польщі від смерті Владислава IV» В. Коховського та «Щоденник» С. Освєнціма. Природно, що автори цих джерел мали пропольську позицію. Так, для В. Коховського Б. Хмельницький уособлював головну причину нещасть Речі Посполитої. Хроніст, а услід за ним і Л. Кубаля, хоч і визнавав полководницький та дипломатичний хист козацького гетьмана, дуже часто приписував йому слова або дії, які були вигадками автора. Наприклад, один із перших успіхів козаків під Зборовом Л. Кубаля, посилаючись на В. Коховського, пояснив так: «На дорозі від Збаража до Зборова (...) ріс великий дуб. Там, як оповідають, заховався Хмельницький (...) иіле військо польське перерахував і оглянув поле битви» [21, 139].

Третій том «Історичних нарисів» з'явився друком у 1910 р. Слід зазначити, що з часом у Л. Кубалі дещо змінився підхід до написання власних праць: якщо перші два томи - це збірка окремих яскравих сюжетів 3 історії українсько-польського протистояння, то наступні дослідження, які хоч і були так само презентовані у формі шкіців, мали значно більш цілісну структуру і були присвячені, як зазначив сам автор, історії «північної семилітньої війни» [24, I].

Незважаючи на те, що нариси хронологічно стосувалися подій після 1654 р., дослідник звернув окрему увагу на діяльність Б. Хмельницького перед Переяславською радою. Висвітлення політики гетьмана до Переяслава мало у дослідника дві мети. По-перше, між першими двома томами і третім томом «Історичних нарисів» була тридцятирічна перерва, тому нарис «Богдан Хмельницький і його діяльність до 1654 р.», який розпочинає третю серію нарисів, став своєрідною актуалізацією подій для читача. По-друге, Л. Кубаля вважав, що однією з причин «північної семилітньої війни», яка точилася протягом 1654 - 1660 рр., стала політика Б. Хмельницького: «Хмельницький піддався в 1654 р. Москві і накликав війну, яку описати прагну» [15, 6-7].

Історик, як і більшість інших дослідників, які писали про події повстання і зверталися до постаті гетьмана, порушив питання щодо його походження. Л. Кубаля дотримувався думки про його нешляхетське походження: «народився в Черкасах, ймовірно в 1596 році, був сином заможного козаџького сотника i підстарости чигиринського». Дослідник припустив, що, можливо, 
майбутній гетьман мав військове шляхетство, але підкреслив, шо воно жодним чином не підтверджене [15, 19-20].

Для тодішніх дослідників історії Хмельниччини походження гетьмана відігравало істотну роль у відображенні причин і перебігу повстання, адже одна справа, коли повстає шляхтич, а інша - коли на виступ насмілюється звичайний козак. Ця проблема піднімалася ще в джерелах часів повстання, які зазвичай характеризували походження Б. Хмельницького як низьке або «плебейське». Прикладом може бути праця польського хроніста В. Коховського. Наголошення на низькому соціальному статусі мало занизити значення постаті Б. Хмельницького в очах читача. Наприклад, це можна помітити і в дослідженнях львівського історика-аматора Ф. Равіти-Гавронського, який популяризував версію про єврейське походження Б. Хмельницького [13, 170-171].

Висвітлюючи це питання, Л. Кубаля спробував показати всю його складність. Історик докладно проаналізував цю проблему, але зробив це переважно у посиланнях [24, 339]. 3 цього приводу слід наголосити, що сучасна польська дослідниця В. Юлковська, припустила, що для того, аби не руйнувати художньої нарації, історик усі суперечливі питання, пов'язані з тою чи тою проблемою, висвітлював у посиланнях $[11,172]$.

Діяльність Б. Хмельницького до початку повстання польський історик охарактеризував як гідну довіри і корисну для підтримання політичної стабільності Речі Посполитої. Більше того, як таку, що взагалі не вказувала на підготовку до бунту: «...ніколи не бував в жодних повстаннях чи свавільних козаџьких бунтах, завжди був вірний війську Речі Посполитої» [15, 20-22].

Якщо у попередніх дослідженнях Л. Кубаля більше характеризував Б. Хмельницького як бунтівника та неприятеля, то у пізніших нарисах гетьман набрав рис державного діяча і постав творцем козацької держави, ідея якої, на думку історика, прийшла йому після перших несподіваних перемог над коронним військом. Л. Кубаля підкреслив: «виникла в його голові ідея козацької держави, кордони якої хотів поширити на територію цілої польської Русі, тобто на київську митрополію $[15,9]$. I саме з позиції державного діяча Л. Кубаля порівняв українського гетьмана з О. Кромвелем.

Тяжкість умов, в яких перебував Б. Хмельницький, на відміну від О. Кромвеля, була пов'язана, на думку Л. Кубалі, з тим, що його влада з усіх боків мала відкриті кордони. Окрім того, «..все треба було створювати: фінанси, господарство, адміністрацію, стосунки з сусідніми державами. Мусив добирати і навчати людей, вдивлятися в найдрібніші деталі. А те, щзо його військо не помирало з голоду, що воно мало зброю, гарних шпигунів і вигідних агентів, щяо йому ніколи не бракувало грошей... то його особиста заслуга, якій можна позаздрити і не лише у нас у Польщзі» [15, 7-8].

Щодо держави Б. Хмельницького, історик спробував проаналізувати чинники, які допомагали iї будувати. Зокрема він уважав, що непересічне значення у цьому питанні мала козацька старшина, яка оточувала Б. Хмельницького та переважно належала до числа його родичів. Саме вона відігравала визначну роль у придушені бунтів, які часто виникали серед козаків, особливо після поразок козацького війська $[15,12]$.

Л. Кубаля позитивно відгукувався також про генеральну військову канцелярію часів Б. Хмельницького, яку очолював Іван Виговський. Історик підкреслював надзвичайну ретельність, з якою у ній велася кореспонденція, особливо міжнародна: «Гетьман мав власних секретарів $і$ пильнував, аби листи до султана, иісаря, хана, шведського короля, лорда протектора, до Ракочі і обох господарів, і до всіх чиновників, і впливових осіб у Москві, в Туреччині, в Криму і в Польщі були правильні в титулах, формі і навіть написані відповідним стилем. Найбільш важливі, здається, редагував сам» $[15,12]$.

Хоч пізнішим нарисам притаманний менший ступінь белетризації в описах, у них також не обійшлося без романтичних нот в образі гетьмана. Так само як і в нарисі «Облога Збаража і битва під Зборовом», тут можна зустріти неодноразові згадки про пияцтво Б. Хмельницького. Але, на відміну від попередніх текстів, тут його пристрасть до алкоголю виглядає виправданою: «А пив до смерті, коли мусив робити, те, чого не хотів» $[15,18]$. Також, на відміну від ранніх нарисів, тут пияцтво не впливало на політику гетьмана: «Але пиящтво $і$ зрушення, яким так легко піддавався, 
не мали впливу на перебіг публічних справ. Був подібний до бездонної холодної глибини, яка залишається непорушною, хоч на ї̈ поверхні величезні бурі бушують» [15, 18-19].

Проте слід зазначити, що, незважаючи на такі досить позитивні характеристики, для Л. Кубалі Б. Хмельницький залишався все ж зрадником та бунтівником: якщо Олівер Кромвель, на його думку, «підносив свою батьківщину, то другий [Б. Хмельницький - О. П.] - ї̈ нищив $i$ зраджував» $[15,8-9]$.

Примітною відмінністю нарисів, опублікованих після 1910 р., стало помітне розширення джерельної бази дослідження за рахунок джерел суто козацького походження - літописів та матеріалів «АЮЗР», праць таких українських істориків, як Дмитро Бантиш-Каменський, Микола Маркович та Ізмаїл Срезневський. Можна припустити, що знайомство з цими джерелами та літературою сприяло виваженості образу Б. Хмельницького, тобто Л. Кубаля всіляко намагався показати постать гетьмана та його значення як для польської, так і для української сторони. Зокрема більш детально почав вимальовуватись образ Б. Хмельницького-оборонця православної віри, особливо у нарисі, який стосувався Переяславської ради (1654). Саме православ'я, відповідно до логіки Л. Кубалі, стало основою вибору Московського царства як нового союзника для гетьмана Б. Хмельницького. І саме таку аргументацію подав історик у промові гетьмана у Переяславі: «(...) прагну народ руський з неволі визволити, за віру православну воювати ...» $[22,50]$.

Також історик наголошував на порівнянні Б. Хмельницького з Мойсеєм: до Києва гетьман «в ’̈жджав 24 грудня, в неділю ввечері, серед пострілів гармат $і$ дзвонів. Весь люд вибіг $і$ вітав його, як Мойсея, рятівника, визволителя» $[15,25]$. Таке порівняння може бути свідченням того, що історик намагався показати значенням гетьмана для усього руського населення та козаків.

Власне намагання Л. Кубалі продемонструвати значення постаті гетьмана для обох конфліктних сторін добре простежується в описі смерті та поховання Б. Хмельницького. Демонструючи польську точку зору, історик тут цитував В. Коховського: «помер (...) підлий трунар спокою, щяо Крим, Москву, Дакію, Семиграддя і оттоманську державу на нас кинув - тягар для Польщі, кара Божа для Русі» $[25,214]$. Козацька сторона істориком представлена досить промовистою непрямою цитатою з «Истории Малороссии» М. Маркевича: «Сироти ми нещасні-батьку, куди ж ти подівся? Хто про нас буде думати? Хто захистить від ворогів? Хто нас рятувати буде? Зайшло наше сонце, а ми на загибель лишилися!» [25, 215]. У самій праці цього історика першої половини XIX ст. цей опис виглядає так: «Кто теперь поженет врагов наших и защзитит нас от них? Померкло солнце наше! мы остались врагам на расхищение» [3]. Як бачимо, польський історик додав два вирази до слів з роботи М. Маркевича, але саме вони презентують Б. Хмельницького не лише як гетьмана, яких до нього було багато, а й як «батька руського народу». Окрім цього, Л. Кубаля констатував, що гетьман, до того ж, став творцем козацької держави: «Туm у Cуботові (...) знаходиться гроб Хмельницького, а з ним похована $і$ козацька держава» $[25,216]$.

Висновки. Постать Б. Хмельницького у дослідженнях Л. Кубалі загалом посідала вагоме місце. Більшість дослідників, які звертали увагу на образ козацького гетьмана у творчості польського історика, підкреслювали складність та суперечливість цього персонажу. У проаналізованих вище дослідженнях бачення польським істориком постаті Б. Хмельницького розглядалися переважно суто статично, тобто без еволюції та змін. Більшість істориків торкалися цього питання у контексті більш конкретних проблем та у рамках синтетичних оглядів історії подій та регіону, про які писав Л. Кубаля. Цікаву спробу проаналізувати загальний образ Б. Хмельницького у творчому доробку польського історика чи не вперше зробила А. Ткачук. Вона зауважила різницю у зображенні Б. Хмельницького у перших двох томах «Історичних нарисів» та пізніших дослідженнях, але більш детального висвітлення ця проблема у дослідженнях авторки не отримала.

Творчість Л. Кубалі, а відповідно і формування образу Б. Хмельницького у його дослідженнях, можна розділити на два етапи. Основу джерельної бази для перших за часом появи тематичних досліджень історика склали польські джерела, переважно хроніки Я. Рудавського, В. Коховського, Й. Срлича, які не відрізнялися позитивним трактуванням постаті та діяльності козацького гетьмана. Тому часто Л. Кубаля, дотримуючись джерела, зображав Б. Хмельницького як неприятеля та ворога. Окрім того, не можна залишити поза увагою вплив на його наукову діяльність з боку драматургічного доробку Л. Кубалі. 3 високим ступнем ймовірності можна припустити, що саме 
драматичність такого персонажу як Б. Хмельницький була перенесена до нарисів з неопублікованої дотепер драми «Русь» («Богдан Хмельницький»). Про вплив письменницької діяльності на наукові праці автора свідчить також присутність у них авторської емпатії та формування чіткої структури «герой - антигерой» в «Історичних нарисах».

Другий етап досліджень історика відзначився зміною підходу до написання нарисів та розширенням джерельної бази за рахунок охоплення джерел козацького походження. Зокрема, помітно збільшилась у його дослідженнях кількість використаних матеріалів «АЮЗР». Знайомство з цими дослідженнями посприяло виваженості суджень історика щодо постаті гетьмана та його діяльності. Свідченням цього може бути зміщення акценту з образу бунтівника на образ державного діяча та намагання автора подати у власних творах порівняти погляди на діяльність Б. Хмельницького, характерні для представників обох протиборчих сторін.

\section{СПИСОК ВИКОРИСТАНИХ ДЖЕРЕЛ ТА ЛІТЕРАТУРИ}

1. Грушевський М. Історія України-Руси: в 11 т., 12 кн. / М. Грушевський / ред.: П. Сохань та ін. - К.: Наукова думка, 1997. - Т. 9. - Кн. 2. - 776 с.

2. Дорошенко Д. Огляд української історіографії / Д. Дорошенко / упорядн.: Ю. Пінчук, Л. Гриневич. - К., 1996. -188 с.

3. Маркевич М. История Малороссии / М. Маркевич. - М., 1842. - Т. 1. - 386 с.

4. Плохій С. Великий переділ. Незвичайна історія Михайла Грушевського / С. Плохій. - К.: Критика, 2011. -598 c.

5. Ткачук А. Постать Богдана Хмельницького в творчому доробку Людвіга Кубалі / А. Ткачук // Чорноморський вісник. - 2014. - №10. - С. 137-141.

6. Ярмошик І. Берестецька битва 1651 р. в наукових дослідженнях польських авторів / I. Ярмошик // Грані. - 2012. - № 3. - С. 3-6.

7. Ясь О. В. Історія як сюжет. Представлення образу Б. Хмельницького в однойменній монографії М. І. Костомарова / О. В. Ясь // Український історичний журнал. - 2007. - № 2. - С. 89-106.

8. Barycz H. Wśród gawędziarzy, pamiętnikarzy i uczonych galicyjskich: studia i sylwety z życia umysłowego Galicji XIX w. / H. Barycz. - Kraków: Wydawnictwo Literackie, 1963. - T. 1. - $426 \mathrm{~s}$.

9. Basarab J. Pereiaslav 1654: A Historiografical study / John Basarb. - Edmonton: The Canadian Institute of Ukrainian Studies. The University of Alberta, 1982.

10. Franz M. Ludwik Kubala jako historyk dziejów wojskowości kozaczyzny zaporoskiej / M. Franz // Studia z dziejów polskiej historiografii wojskowej. - Poznań. - T. III. - S. 31-48.

11. Julkowska V. Historia opowiadająca Karola Szajnochy i Ludwika Kubali / V. Julkowska // Багатокультурне історичне середовище Львова в XIX і XX століттях. - Львів-Жешув, 2006. - Т. 4. - S. 154-177.

12. Julkowska V. Polski esej historyczny w XIX i XX wieku. Część I. Szkice historyczne Szajnochy i Kubalinarodziny polskiego eseju historycznego / V. Julkowska // Klio Polska. Studia i materiały z dziejów historiografii polskiej XIX - XX wieku. -Warszawa, 2011. - T. 5. - S. 63-94.

13. Koko E. Franciszek Rawita-Gawroński (1846 - 1930) wobec Ukrainy i jej przeszłości / E. Koko. Gdańsk, 2006. -274 s.

14. Kubala L. Bitwa pod Beresteczkiem / L. Kubala // Szkice historyczne. Serya pierwsza. - Lwów: Nakład Gubrynowicza i Schmidta, 1881. - S. 234-303.

15. Kubala L. Bogdan Chmielnicki i jego działalność do r. 1654 / L. Kubala // Szkice historyczne. Serya trzecia. Wojna moskiewska r. 1654 - 1655. - Warszawa: Nakład Gebethnera i Wolfa, 1910. - S. 1-46.

16. Kubala L. Gliński / L. Kubala // Dziennik Literacki. - 1866. - R. 15. - № 43. - S. 676-678.

17. Kubala L. Jerzy Ossoliński / L. Kubala. - Lwów: Gubrynowicz i Schmidt, 1883. - T. 2.- 386 s.

18. Kubala L. Jerzy Ossoliński / L. Kubala. - T. 1. - Lwów: Gubrynowicz i Schmidt, 1883. - 366 s.

19. Kubala L. Krwawe Swaty / L. Kubala // Szkice historyczne. Serya druga. - Lwów: Nakład Gubrynowicza i Schmidta, 1880. - S. 133-154.

20. Kubala L. Oblężenie Lwowa w roku 1648 / L. Kubala // Szkice historyczne. Serya pierwsza. - Lwów: Nakład Gubrynowicza i Schmidta, 1881. - S. 75-102.

21. Kubala L. Oblężenie Zbaraża i pokój pod Zborowem / L. Kubala // Szkice historyczne. Serya pierwsza. Lwów: Nakład Gubrynowicza i Schmidta, 1881. - S. 103-183.

22. Kubala L. Przysięga w Pereasławiu. Zajęcie Kijowa przez Moskwę i zatarg prawosławnej ruskiej cerkwi z patryarchatem moskiewskim. - «Stati» Bohdana Chmielnickiego / L. Kubala // Szkice historyczne. Serya trzecia. Wojna moskiewska r. 1654 - 1655. - Warszawa: Nakład Gebethnera i Wolfa, 1910. - S. 47-90. 
23. Kubala L. Stanisław Orzechowski i wpływ jego na Rzeczpospolitą wobec Reformacji XVI wieku. Rzecz historyczna / L. Kubala. - Lwów: Wild, 1870. - 120 s.

24. Kubala L. Szkice historyczne. Serya trzecia. Wojna moskiewska r. 1654 - 1655 / L. Kubala. - Warszawa: Nakład Gebethnera i Wolfa, 1910. - 443 s.

25. Kubala L. Śmierć Chmielnickiego / L. Kubala // Wojna Brandenburska i najazd Rakoczego w roku 1656 i 1657 (szkiców historycznych serya V). - Lwów: Z drukarni przy Zakładzie Narodowym imienia Ossolińskich. S. $185-216$.

26. Kubala L. Wyprawa Żwaniecka / L. Kubala // Szkice historyczne. Serya druga. - Lwów: Nakład Gubrynowicza i Schmidta, 1880. - S. 173-289.

27. Kubiak A. Badania nad dziejami wojskowości w twórczości Ludwika Kubali / A. Kubiak // Studia z dziejów polskiej historiografii wojskowej. - Poznań, 1975. - T. 1. - S. 101-115.

28. Litwos [H. Sienkiewicz]. Mięszaniny literacko-artystyczne XI. Szkice L. Kubali // Niwa. - 1880. S. 607-618.

29. Romek Z. Ludwik Kubala (1838 - 1918) / Z. Romek // Złota Złota księga historiografii lwowskiej XIX i XX wieku / red. J. Maternicki, L. Zaszkilniak. - Lwów: Wyd-wo Un-tu Rzeszowskiego, 2007. - S. 181-200.

30. Srogosz T. Postacie Kozaków w historiografii Ludwika Kubali / T. Srogosz // Нові дослідження пам'яток козацької доби в Україні. - К., 2012. - Вип. 21. - Ч. II. - С. 88-91.

31. Sysyn F. The Changing Image of the Hetman: On the 350th Anniversary of the Khmel'nyts'kyi Uprising / F. Sysyn // Jahrbücher für Geschichte Osteuropas, Neue Folge - 1998. - Bd. 46. - H. 4. - P. 531-545.

32. Zakład Narodowy im. Ossolińskich, Rkps. 12918 «Dramat Ruś». - S. 1-148.

33. Zakład Narodowy im. Ossolińskich, Rkps. 12919/I «Dramaty Ludwika Kubali». - S. 1-46.

\section{REFERENCES}

1. Hrushevskyi M. Istoriia Ukrainy-Rusy: v 11 t., 12 kn. / M. Hrushevskyi / red.: P. Sokhan ta in. - K.: Naukova dumka, 1997. - T. 9. - Kn. 2. $-776 \mathrm{~s}$.

2. Doroshenko D. Ohliad ukrainskoi istoriohrafii / D. Doroshenko / uporiadn.: Yu. Pinchuk, L. Hrynevych. K., 1996. $-188 \mathrm{~s}$.

3. Markevych M. Ystoryia Malorossyy / M. Markevych. - M., 1842. - T. 1. - 386 s.

4. Plokhii S. Velykyi peredil. Nezvychaina istoriia Mykhaila Hrushevskoho / S. Plokhii. - K.: Krytyka, 2011. $-598 \mathrm{~s}$.

5. Tkachuk A. Postat Bohdana Khmelnytskoho v tvorchomu dorobku Liudviha Kubali / A. Tkachuk // Chornomorskyi visnyk. - 2014. - №10. - S. 137-141.

6. Iarmoshyk I. Berestetska bytva $1651 \mathrm{r}$. v naukovykh doslidzhenniakh polskykh avtoriv / I. Yarmoshyk // Hrani. - 2012. - № 3. - S. 3-6.

7. Ias O. V. Istoriia yak siuzhet. Predstavlennia obrazu B. Khmelnytskoho v odnoimennii monohrafii M. I. Kostomarova / O. V. Yas // Ukrainskyi istorychnyi zhurnal. - 2007. - № 2. - S. 89-106.

8. Barycz H. Wśród gawędziarzy, pamiętnikarzy i uczonych galicyjskich: studia i sylwety z życia umysłowego Galicji XIX w. / H. Barycz. - Kraków: Wydawnictwo Literackie, 1963. - T. 1. - 426 s.

9. Basarab J. Pereiaslav 1654: A Historiografical study / John Basarb. - Edmonton: The Canadian Institute of Ukrainian Studies. The University of Alberta, 1982.

10. Franz M. Ludwik Kubala jako historyk dziejów wojskowości kozaczyzny zaporoskiej / M. Franz // Studia z dziejów polskiej historiografii wojskowej. - Poznań. - T. III. - S. 31-48.

11. Julkowska V. Historia opowiadająca Karola Szajnochy i Ludwika Kubali / V. Julkowska // Багатокультурне історичне середовище Львова в XIX і XX століттях. - Львів-Жешув, 2006. - Т. 4. - S. 154-177.

12. Julkowska V. Polski esej historyczny w XIX i XX wieku. Część I. Szkice historyczne Szajnochy i Kubali narodziny polskiego eseju historycznego / V. Julkowska // Klio Polska. Studia i materiały z dziejów historiografii polskiej XIX - XX wieku. -Warszawa, 2011. - T. 5. - S. 63-94.

13. Koko E. Franciszek Rawita-Gawroński (1846 - 1930) wobec Ukrainy i jej przeszłości / E. Koko. Gdańsk, 2006. -274 s.

14. Kubala L. Bitwa pod Beresteczkiem / L. Kubala // Szkice historyczne. Serya pierwsza. - Lwów: Nakład Gubrynowicza i Schmidta, 1881. - S. 234-303.

15. Kubala L. Bogdan Chmielnicki i jego działalność do r. 1654 / L. Kubala // Szkice historyczne. Serya trzecia. Wojna moskiewska r. 1654 - 1655. - Warszawa: Nakład Gebethnera i Wolfa, 1910. - S. 1-46.

16. Kubala L. Gliński / L. Kubala // Dziennik Literacki. - 1866. - R. 15. - № 43. - S. 676-678.

17. Kubala L. Jerzy Ossoliński / L. Kubala. - Lwów: Gubrynowicz i Schmidt, 1883. - T. 2.- 386 s.

18. Kubala L. Jerzy Ossoliński / L. Kubala. - T. 1. - Lwów: Gubrynowicz i Schmidt, 1883. - 366 s. 
19. Kubala L. Krwawe Swaty / L. Kubala // Szkice historyczne. Serya druga. - Lwów: Nakład Gubrynowicza i Schmidta, 1880. - S. 133-154.

20. Kubala L. Oblężenie Lwowa w roku 1648 / L. Kubala // Szkice historyczne. Serya pierwsza. - Lwów: Nakład Gubrynowicza i Schmidta, 1881. - S. 75-102.

21. Kubala L. Oblężenie Zbaraża i pokój pod Zborowem / L. Kubala // Szkice historyczne. Serya pierwsza. Lwów: Nakład Gubrynowicza i Schmidta, 1881. - S. 103-183.

22. Kubala L. Przysięga w Pereasławiu. Zajęcie Kijowa przez Moskwę i zatarg prawosławnej ruskiej cerkwi z patryarchatem moskiewskim. - «Stati» Bohdana Chmielnickiego / L. Kubala // Szkice historyczne. Serya trzecia. Wojna moskiewska r. 1654 - 1655. - Warszawa: Nakład Gebethnera i Wolfa, 1910. - S. 47-90.

23. Kubala L. Stanisław Orzechowski i wpływ jego na Rzeczpospolitą wobec Reformacji XVI wieku. Rzecz historyczna / L. Kubala. - Lwów: Wild, 1870. - 120 s.

24. Kubala L. Szkice historyczne. Serya trzecia. Wojna moskiewska r. 1654 - 1655 / L. Kubala. - Warszawa: Nakład Gebethnera i Wolfa, 1910. - 443 s.

25. Kubala L. Śmierć Chmielnickiego / L. Kubala // Wojna Brandenburska i najazd Rakoczego w roku 1656 i 1657 (szkiców historycznych serya V). - Lwów: Z drukarni przy Zakładzie Narodowym imienia Ossolińskich. S. $185-216$.

26. Kubala L. Wyprawa Żwaniecka / L. Kubala // Szkice historyczne. Serya druga. - Lwów: Nakład Gubrynowicza i Schmidta, 1880. - S. 173-289.

27. Kubiak A. Badania nad dziejami wojskowości w twórczości Ludwika Kubali / A. Kubiak // Studia z dziejów polskiej historiografii wojskowej. - Poznań, 1975. - T. 1. - S. 101-115.

28. Litwos [H. Sienkiewicz]. Mięszaniny literacko-artystyczne XI. Szkice L. Kubali // Niwa. - 1880. S. 607-618.

29. Romek Z. Ludwik Kubala (1838 - 1918) / Z. Romek // Złota Złota księga historiografii lwowskiej XIX i XX wieku / red. J. Maternicki, L. Zaszkilniak. - Lwów: Wyd-wo Un-tu Rzeszowskiego, 2007. - S. 181-200.

30. Srogosz T. Postacie Kozaków w historiografii Ludwika Kubali / T. Srogosz // Нові дослідження пам’яток козацької доби в Україні. - К., 2012. - Вип. 21. - Ч. ІІ. - С. 88-91.

31. Sysyn F. The Changing Image of the Hetman: On the 350th Anniversary of the Khmel'nyts'kyi Uprising / F. Sysyn // Jahrbücher für Geschichte Osteuropas, Neue Folge - 1998. - Bd. 46. - H. 4. - P. 531-545.

32. Zakład Narodowy im. Ossolińskich, Rkps. 12918 «Dramat Ruś». - S. 1-148.

33. Zakład Narodowy im. Ossolińskich, Rkps. 12919/I «Dramaty Ludwika Kubali». - S. 1-46.

Стаття надійшла до редакиії 20.11.2017 p. 